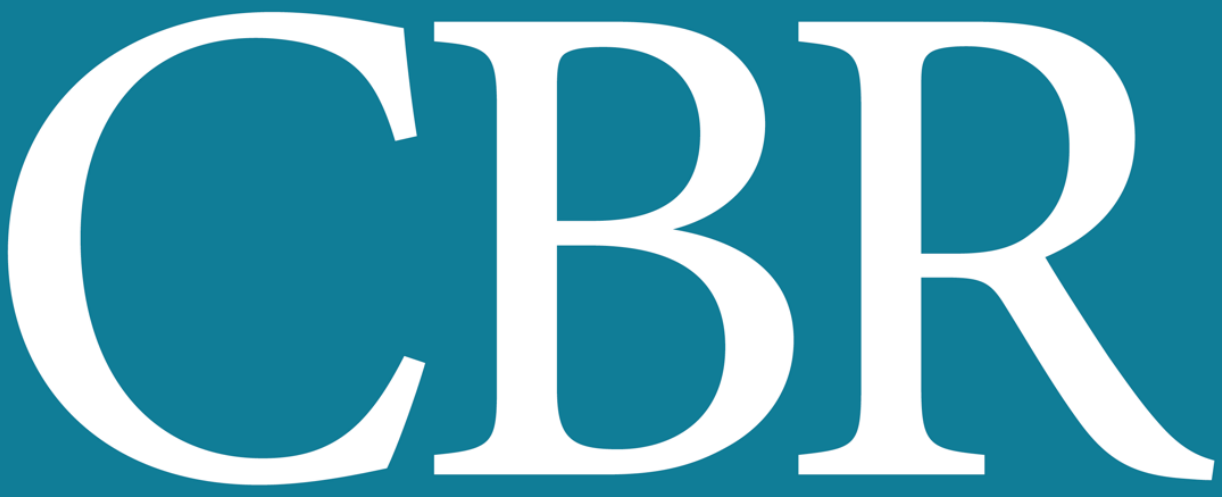

INTERNATIONAL JOURNAL OF CANCER AND BIOMEDICAL RESEARCH

https://jcbr.journals.ekb.eg

Editor-in-chief

Prof. Mohamed Labib Salem, PhD

Assessment of PD-L1 and p53 expression in urinary bladder carcinoma: Association with different clinicopathologic characteristics

Nehal A. Heabah and Asmaa E. Bedeer 


\section{Welcome letter from Editor-in-Chief}

Welcome to the Int J Cancer and Biomedical Research (IJCBR)!

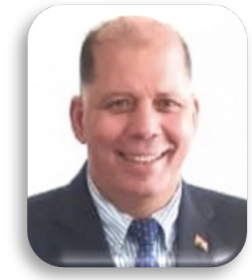

It is with great pleasure that I write this editorial to welcome you to the IJCBR. This journal provides a platform for publication of original and reviews research articles, short communications, letter to editor, thesis abstract, conference report, and case studies. These types of publication are directed at the interface of the fields of cancer and biomedical research.

The IJCBR relies on a distinguished expert of the Advisory and Editorial Board Members from the top international league covering in depth the related topics. They timely review all manuscripts and maintain highest standards of quality and scientific methodology and ethical concepts. Meanwhile, we take all possible means to keep the time of the publication process as short as possible.

I take this chance to welcome your contributions to the IJCBR and have every expectation that it will soon become one of the most respected journals in both the fields of cancer and biomedical research.

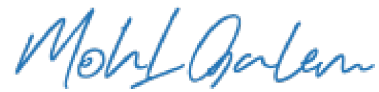

Mohamed L. Salem,

Editor in Chief 


\title{
Assessment of PD-L1 and p53 expression in urinary bladder carcinoma: Association with different clinicopathologic characteristics
}

\author{
Nehal Abd El-Ghaffar Heabah and Asmaa E. Bedeer \\ Pathology Department, Faculty of Medicine, Tanta University, Egypt
}

III

Background: Urinary bladder carcinoma is the most common urologic malignancy that includes phenotypically and genotypically diverse tumors. The development of new treatment modalities is essential to improve the outcomes and increase the overall survival of urinary bladder carcinoma patients'. Among these modalities, comes the PD-L1 inhibitors, as promising immunotherapy. P53 may also play a role in these treatment strategies. Aim: This study aimed to evaluate PD-L1 and p53 expression in urinary bladder carcinoma, and its available variants, and relate PD-L1 and p53 expression to each other and the available clinicopathological features. Materials and methods: This study included 60 cases of urinary bladder carcinoma, with no history of radiotherapy or chemotherapy, classified as follows: 32 cases of urothelial carcinoma, 25 squamous cell carcinomas, and 3 adenocarcinomas. Immunohistochemical staining of all cases using PD-L1 and p53 was done. Results: Positive PD-L1 expression was detected in $51.7 \%$ of all cases. PD-L1 expression was significantly associated with the histopathological types, high tumor grade and muscle invasion. High p53 expression was detected in 50\% of the studied cases. P53 expression was significantly associated with high tumor grade, advanced stage, vascular invasion and lymph node metastasis. PD-L1 and p53 co-expression was detected in $33.3 \%$ of the cases. PD-L1 positivity was significantly associated with p53 expression. Conclusions: PD-L1 and p53 could be considered as predicting biomarkers for aggressive bladder carcinoma and their immunohistochemical expression may aid in identifying suitable patients for target therapy.

Keywords: Urinary bladder carcinoma; immune checkpoints; PD-L1; P53
DU ARTICLE INFO

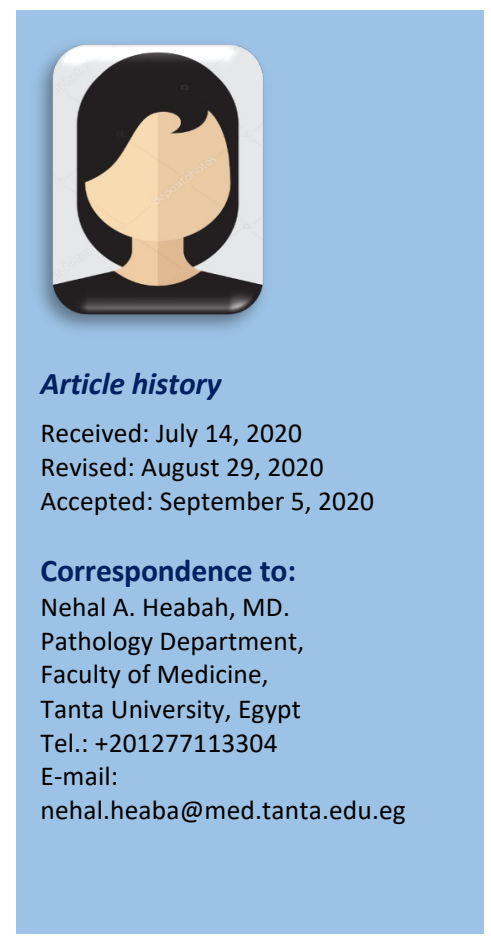

Editor-in-Chief: Prof. M.L. Salem, PhD - Article DOI: 10.21608/JCBR.2020.35710.1054

\section{INTRODUCTION}

Urinary bladder carcinoma is a major worldwide health problem with a high death rate (Siegel et al., 2019). The development of new treatment modalities is crucial to improve the outcomes and increase the overall survival of urinary bladder carcinoma patients' (Patel and Kurzrock, 2015).

Immunotherapy is a promising strategy for the treatment of different cancers. Cancer immunotherapy starts with a proper understanding of tumor immuno-biology (Bellmunt et al., 2017). Study of the tumor microenvironment revealed the importance of immune checkpoints in facilitating tumor immunological escape, leading to the development of multiple novel therapeutics targeting the PD-1/PD-L1 (programmed cell death protein 1, CD279; programmed deathligand 1, CD274) immune checkpoints (Brahmer et al., 2012 and Topalian et al., 2012).

PD-1 is a T-cell immune inhibitory checkpoint that dampens T-cell activation and contributes to the immunosuppressive tumor microenvironment. PD-1 is also expressed on activated B cells and NK cells (Pardoll, 2012). PD1 is activated by binding to its ligand; PD-L1, which is a cell surface glycoprotein. Many cell types express PD-L1, including placenta, vascular endothelium, hepatocytes and mesenchymal stem cells, also B cells, T cells, dendritic cells, macrophages, and mast cells (Sharpe et al., 2007). 
The binding of PD-L1 on the tumor cells to PD-1 on $T$ cells- leads to the generation of a tumor that evades immune surveillance by multiple immuno-inhibitory mechanisms, as well as, contributes to the development of T-cell exhaustion and peripheral immunologic tolerance. This binding also decreases immunogenic antigen presentation by the tumor and creates an immunosuppressive state via a process termed "immune-editing" (Kawahara et al., 2018 and Ding et al., 2019).

The blockage of the PD-1/PD-L1 interaction led to good clinical responses in several cancer types. Yet, determining which patients gain benefit from PD-1/PD-L1-directed immunotherapy remains an important clinical question. Data suggest that patients whose tumors overexpress PD-L1 by IHC have improved responses with anti-PD-1-directed therapy, but the strong responses in some patients with low expression of these markers make this process controversy (Patel and Kurzrock, 2015).

Most human cancers result from mutations of cell-cycle regulatory genes, which control DNA synthesis and replication. In bladder carcinoma, the most studied cell-cycle molecule is p53 a tumor suppressor gene on chromosome $17 \mathrm{p} 13$ that prevents genomic mutation. Mutations of p53 lead to tumor generation (Favaretto et al., 2018).

P53 status is considered a biomarker of progression, disease-free and disease-specific survival in both non-muscle invasive (NMI) and muscle-invasive (MI) bladder carcinoma. In NMI bladder carcinoma, p53 overexpression is associated with higher progression rates, while in $\mathrm{MI}$ bladder carcinoma, it's associated with increasing tumor stage (Rodriguez-Alonso et al., 2002 and Shariat et al., 2010). P53 expression may also impair the response to cisplatin-based chemotherapy in advanced bladder cancer, so p53-negative patients exhibit a more favorable response (Jankevicius et al., 2002). P53 plays a role in controlling PD-L1 expression and regulating the immune responses (Braun and Iwakuma, 2016; Muñoz-Fontela et al., 2016). Cortez et al. (2016) revealed that wild-type p53 decreases PD-L1 expression via up-regulating miR-34, in non-small cell lung cancer cell lines.
Members of the miR-34 family are effector molecules, induced by wild-type p53, and act as a link between PD-L1 and p53 (Heinemann et al., 2012).

However, little is known about the role of PD-L1 and its relation to p53 in urinary bladder carcinoma including its different histopathological variants. In this study, we aimed to evaluate PD-L1 and p53 expression in urinary bladder carcinoma, and its available variants, and relate PD-L1 and p53 expression to each other, and the available clinicopathological features.

\section{MATERIALS AND METHODS}

This retrospective study was carried out on 60 biopsies of primary bladder carcinomas. Formaline fixed paraffin-embedded blocks were collected from the archives of the Pathology Department, Faculty of Medicine, Tanta University during the period of the study (from May 2019 to June 2020). Tissue specimens were in the form of 40 transurethral resections of bladder tumors (TURBT) and 20 radical cystectomy specimens. The cases were categorized as follows: 32 cases of urothelial carcinoma, 25 cases of squamous cell carcinoma and 3 cases of adenocarcinoma. Cases are classified and graded according to 2016 WHO classification of bladder tumors (Humphery et al., 2016).

All specimens were fixed in $10 \%$ formalin solution and embedded in paraffin for routine histopathologic examination. The clinicopathological characteristics assessed for each case- included: the age, sex, histologic type, tumor grade, concomitant carcinoma in situ (CIS), lymphovascular and perineural invasion, and TNM staging. Tumor staging was done according to the American Joint Committee on Cancer (AJCC) -TNM classification of bladder tumors (eighth edition) (Amin et al., 2017). We took the approval of the Local Research Ethics Committee, Faculty of Medicine, Tanta University, before conducting this study.

Immunohistochemistry: Representative tissue sections were deparaffinized in xylene, rehydrated in descending alcohol grades then incubated with an anti PD-L1 antibody, a mouse 
monoclonal antibody (clone 1C10: sc-293425, Santa Cruz Biotechnology, INC, USA) at 1:100 dilution, and an anti-p53 antibody, a mouse monoclonal antibody (clone DO-1: sc-126, Santa Cruz Biotechnology, INC, USA) at 1:100 dilution. This is done after antigen retrieval by microwave incubation in $6.1 \mathrm{PH}$ citrate buffer for 20 minutes and blocking endogenous peroxidase by $\mathrm{H}_{2} \mathrm{O}_{2}$. Visualization was obtained by the streptavidin-biotin $A B C$ detection kit (Catalog \# TA-015-HP, Lab-Vision Corporation Fremont, USA). Colour development was done using 3,3 diaminobenzidines and Meyer Hematoxylin as a counterstain. Slides were mounted with DPX and coverslipped. Negative control was done by omitting the step of the primary antibody.

\section{Assessment of PD-L1 and P53 immunohistochemical staining}

Positive PD-L1 immunostaining was defined by the presence of $\geq 5 \%$ membranous staining of the tumor cells (Bellmunt et al., 2015). P53 positivity was seen as nuclear staining. The percentage of immunopositive cells was calculated by counting at least 1000 tumor cells in areas of maximum positivity. The results were interpreted taking the cutoff value as $20 \%$ and divided into 0 as negative, $<20 \%$ as low, and $>20 \%$ as high p53 expression (Thakur et al., 2017). For Statistical purposes, cases were grouped as low expression (negative $\&<20 \%$ ) and high expression (>20\%).

\section{Statistical analysis}

Statistical analysis was performed using Statistical Package for Social Science (SPSS version 23.0). Data were presented as mean \pm SD for numerical variables and frequencies for categorical ones. For comparing categorical data, Chi-square $(\chi 2)$ test was used as a test of significance. Fisher's exact test or Monte Carlo was used when one or more cells have an expected frequency of five or less. $P$ values of $<$ 0.05 were considered statistically significant.

\section{RESULTS}

\section{Clinicopathological data}

The clinicopathologic characteristics of the studied cases are summarized in Table 1.

\section{Immunohistochemical staining results of PD-L1}

Positive PD-L1 expression was demonstrated as membranous staining in 31 cases $(51.7 \%)$. The relation between the immunohistochemical staining results of PD-L1 expression and different clinicopathological parameters is summarized in Table 2. Among the 32 urothelial carcinomas, 10 cases (31.2\%) showed PD-L1 positive expression: 2/12 (16.7\%) high grade infiltrating urothelial carcinoma, 6/10 (60\%) urothelial carcinoma with squamous differentiation and $2 / 2$ (100\%) sarcomatoid urothelial carcinoma. Eighteen cases $(72 \%)$ out of 25 SCC cases were PD-L1 positive. All the 3 adenocarcinoma cases showed PD-L1 positivity (Figure 1). There was a statistically significant relation between PD-L1 expression and the various histopathological types $(P=0.001)$, high tumor grade $(P=0.023)$ and advanced stage $(P$ $=0.01)$. No significant relation was detected between PD-L1 expression and patients' sex, associated carcinoma in situ, lymph node status and vascular and perineural invasion.

\section{Immunohistochemical staining results of p53}

High p53 expression was demonstrated as brownish nuclear staining in $30(50 \%)$ out of the 60 studied cases. The relation between the immunohistochemical staining results of p53 expression and the different clinicopathological parameters is summarized in Table 3.

Among the 32 urothelial carcinomas, 17 cases (53.1\%) showed high p53 expression: $2 / 8$ (25\%) low grade non infiltrating papillary urothelial carcinoma, 6/12 (50\%) high grade infiltrating urothelial carcinoma, 7/10 (70\%) urothelial carcinoma with squamous differentiation and $2 / 2(100 \%)$ sarcomatoid urothelial carcinoma. Ten cases (40\%) out of 25 SCC cases showed high p53 expression. All the 3 adenocarcinoma cases showed high p53 expression (Figure 2).

There was a statistically significant relation between $\mathrm{p} 53$ expression and high tumor grade $(P=0.003)$, advanced tumor stage $(P=0.032)$, the presence of vascular invasion $(P=0.0078)$ and lymph node metastasis ( $P=0.012)$. No significant relation was detected between p53 expression and patients' sex, histopathological types, associated carcinoma in situ and perineural invasion. 

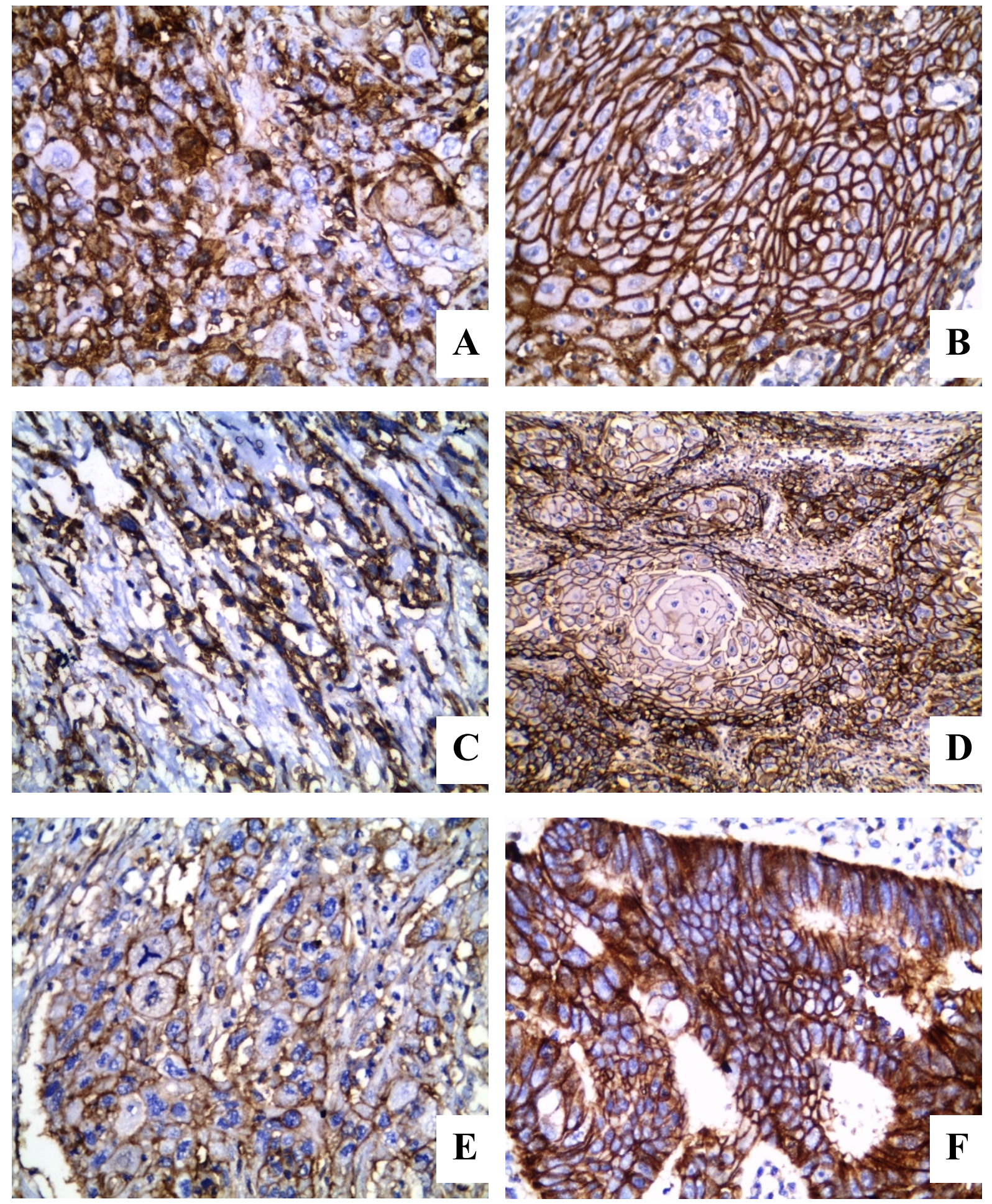

Figure 1. High grade infiltrating urothelial carcinoma ' $x 400$ ' $(A)$, High grade infiltrating urothelial carcinoma with squamous differentiation ' $x 400$ ' $(B)$, Sarcomatoid urothelial carcinoma ' $x 400$ ' $(C)$, Moderately differentiated squamous cell carcinoma ' $x 200$ ' (D), Poorly differentiated squamous cell carcinoma ' $x 400$ ' $(E)$, Moderately differentiated adenocarcinoma ' $x 400$ ' $(F)$, cases from (A-F) show positive membranous PD-L1 expression. 

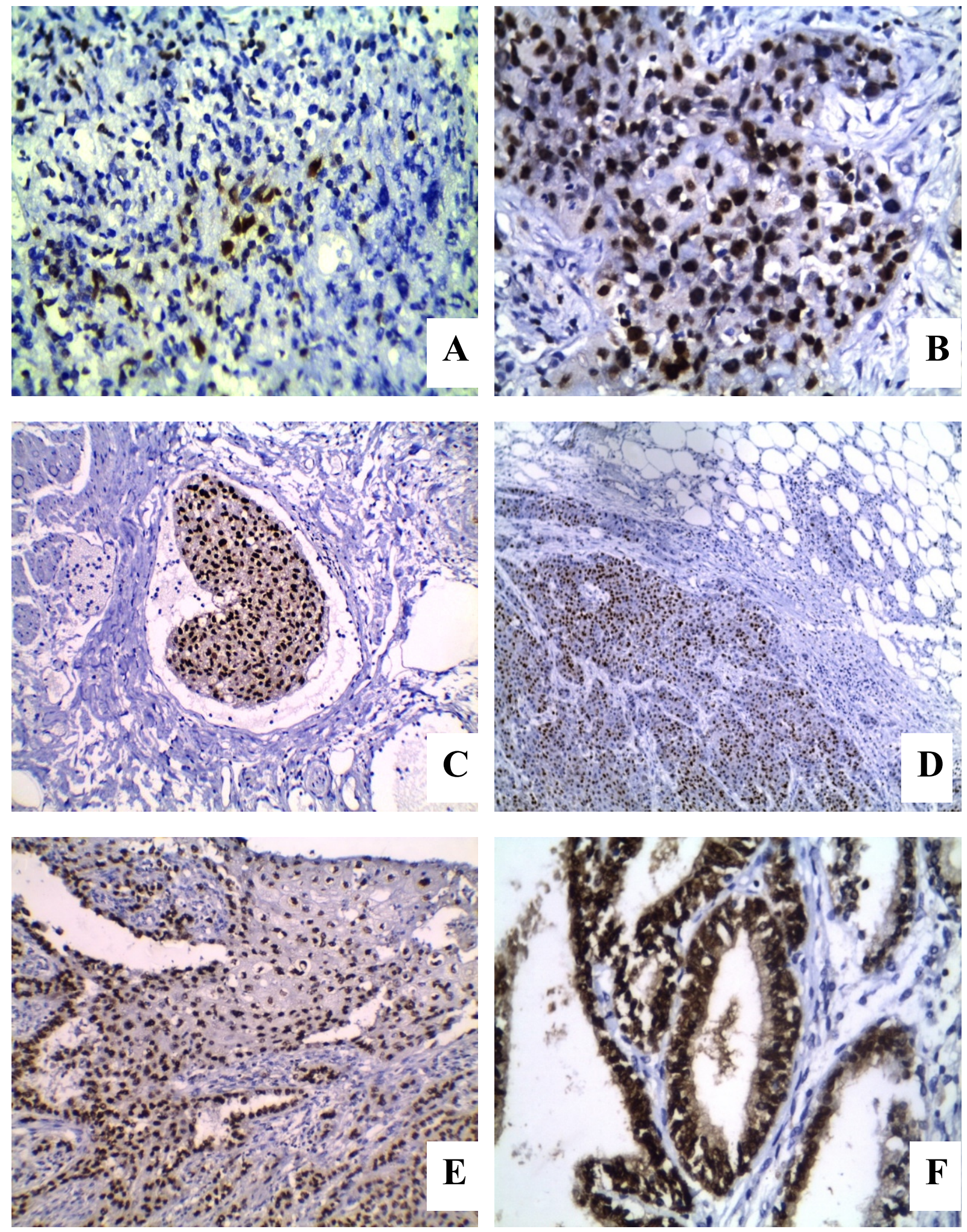

Figure 2. High grade infiltrating urothelial carcinoma showing low $p 53$ expression ' $x 400$ ' $(A)$, High grade infiltrating urothelial carcinoma ' $x 400$ ' $(B)$, High grade infiltrating urothelial carcinoma with vascular emboli ' $x 200$ ' $(C)$, Lymph nodal metastasis of urothelial carcinoma ' $x 100$ '(D), Moderately differentiated squamous cell carcinoma ' $x 200$ ' (E), Moderately differentiated adenocarcinoma ' $x 400$ ' $(F)$, cases form (B-F) show high $\mathrm{p} 53$ expression. 
Table 1. The clinicopathological characteristics of the studied cases

\begin{tabular}{|c|c|c|}
\hline Clinicopathological characteristics & Cases (No.) & $\%$ \\
\hline \multicolumn{3}{|l|}{ Sex } \\
\hline Male & 47 & $78.3 \%$ \\
\hline Female & 13 & $21.7 \%$ \\
\hline \multicolumn{3}{|l|}{ Histopathological types } \\
\hline Urothelial carcinoma (Total) & 32 & $53.3 \%$ \\
\hline Low grade non-infiltrating papillary urothelial carcinoma & 8 & $13.3 \%$ \\
\hline High grade infiltrating urothelial carcinoma & 12 & $20 \%$ \\
\hline Urothelial carcinoma with squamous differentiation & 10 & $16.7 \%$ \\
\hline Sarcomatoid urothelial carcinoma & 2 & $3.3 \%$ \\
\hline Squamous cell carcinoma & 25 & $41.7 \%$ \\
\hline Adenocarcinoma & 3 & $5 \%$ \\
\hline Grade & 21 & $35 \%$ \\
\hline Low & 39 & $65 \%$ \\
\hline \multicolumn{3}{|l|}{$\begin{array}{l}\text { High } \\
\text { Stage }\end{array}$} \\
\hline $\mathrm{NMI}^{1}$ (pTa \& pT1) & 20 & $33.3 \%$ \\
\hline $\mathrm{MI}^{2}(\mathrm{pT} 2, \mathrm{pT} 3 \& \mathrm{pT} 4)$ & 40 & $66.7 \%$ \\
\hline \multicolumn{3}{|l|}{ Associated carcinoma in situ } \\
\hline Absent & 45 & $15 \%$ \\
\hline Present & 15 & $25 \%$ \\
\hline \multicolumn{3}{|l|}{ Vascular invasion } \\
\hline Positive & 9 & $15 \%$ \\
\hline Negative & 51 & $85 \%$ \\
\hline \multicolumn{3}{|l|}{ Perineural invasion: } \\
\hline Positive & 9 & $15 \%$ \\
\hline Negative & 51 & $85 \%$ \\
\hline \multicolumn{3}{|l|}{ Lymph node status } \\
\hline Involved & 17 & $28.3 \%$ \\
\hline Not involved & 43 & $71.7 \%$ \\
\hline
\end{tabular}

1= NMI, Non-muscle invasive, 2= MI, Muscle-invasive.

\section{Relation between PD-L1 and p53 expressions}

There was a significant relation between PD-L1 and $\mathrm{p} 53$ expressions $(P=0.012$ ) (Table 4$)$. PD-L1 and $\mathrm{p} 53$ co-expression was detected in 20 cases out of 60 (33.3\%).

\section{DISCUSSION}

Urinary bladder carcinoma is the most common malignancy of the urinary tract and includes phenotypically and genotypically diverse tumors (Charlton et al., 2014).

In this work, we studied the expression of PD-L1 and p53 in tumor cells of urothelial carcinoma and its squamous and sarcomatoid variants-, squamous cell carcinoma and adenocarcinoma, and we related their expression to different clinicopathological parameters.

PD-L1 recently catches the attention because of its critical role in immunosuppression, facilitating tumor immunologic escape. Only a few studies have investigated the role of PD-L1 expression in urinary bladder carcinoma and its histologic variants and the role of PD-1/PD-L1 inhibitors for treating advanced bladder carcinoma, with inconclusive results. IHC-based detection of PDL-1 helps to determine which tumor histologies may get benefit from PD1/PD-L1 blockage, which is an important step in cancer immunotherapy.

In the current study, positive PD-L1 expression was present in $31.2 \%$ of the urothelial carcinomas, $72 \%$ of the SCCs and $100 \%$ of the adenocarcinomas. Regarding urothelial carcinomas with squamous differentiation, $60 \%$ of cases showed PD-L1 positive expression, and the 2 sarcomatoid urothelial carcinoma cases were also PD-L1 positive.

Our results matched those of Gatalica et al. (2014) who found that $55 \%$ of their bladder carcinoma cases showed PD-L1 positivity. Morsch et al. (2020) found that positive PD-L1 staining was detected in $51.2 \%$ of their cases and that its expression was higher in urothelial carcinoma with squamous differentiation and squamous cell carcinomas, compared with conventional urothelial tumors and stated that 
Table 2. Relation of PD-L1 expression with the different clinicopathological parameters

\begin{tabular}{|c|c|c|c|c|}
\hline Clinicopathological parameters & $\begin{array}{l}\text { Cases } \\
\text { (No.) }\end{array}$ & $\begin{array}{l}\text { Positive PD-L1 } \\
\text { expression } \\
\mathbf{N}=\mathbf{3 1}(\%)\end{array}$ & $\begin{array}{c}\text { Negative PD-L1 } \\
\text { expression } \\
\mathbf{N}=\mathbf{2 9}(\%)\end{array}$ & $\begin{array}{c}P \\
\text { value }\end{array}$ \\
\hline \multicolumn{5}{|l|}{ Sex } \\
\hline Male & 47 & $26(55.3)$ & $21(44.7)$ & 0.282 \\
\hline Female & 13 & $5(38.5)$ & $8(61.5)$ & \\
\hline \multicolumn{5}{|l|}{ Histopathological types } \\
\hline Urothelial carcinoma (Total) & 32 & $10(31.2)$ & $22(68.8)$ & \\
\hline $\begin{array}{l}\text { Low grade non-infiltrating papillary urothelial } \\
\text { carcinoma }\end{array}$ & 8 & $0(0)$ & $8(100)$ & \\
\hline High grade infiltrating urothelial carcinoma & 12 & $2(16.7)$ & $10(83.3)$ & \\
\hline $\begin{array}{l}\text { Urothelial carcinoma with squamous } \\
\text { differentiation }\end{array}$ & 10 & $6(60)$ & $4(40)$ & $0.001^{*}$ \\
\hline Sarcomatoid urothelial carcinoma & 2 & $2(100)$ & $0(0)$ & \\
\hline Squamous cell carcinoma & 25 & $18(72)$ & $7(28)$ & \\
\hline Adenocarcinoma & 3 & $3(100)$ & $0(0)$ & \\
\hline \multicolumn{5}{|l|}{ Grade } \\
\hline Low & 21 & $6(28.6)$ & $15(71.4)$ & $0.023^{*}$ \\
\hline High & 39 & $25(64.1)$ & $14(35.9)$ & \\
\hline \multicolumn{5}{|l|}{ Stage } \\
\hline $\mathrm{NMI}^{1}(\mathrm{pTa} \& \mathrm{pT} 1)$ & 20 & $3(15)$ & $17(85)$ & $0.01 *$ \\
\hline$M I^{2}(p T 2, p T 3 \& p T 4)$ & 40 & $28(70)$ & $12(30)$ & \\
\hline \multicolumn{5}{|l|}{ Associated carcinoma in situ } \\
\hline Absent & 45 & $22(48.9)$ & $23(51.1)$ & 0.456 \\
\hline Present & 15 & $9(60)$ & $6(40)$ & \\
\hline \multicolumn{5}{|l|}{ Vascular invasion } \\
\hline Positive & 9 & $6(66.7)$ & $3(33.3)$ & 0.44 \\
\hline Negative & 51 & $25(49)$ & $26(51)$ & \\
\hline \multicolumn{5}{|l|}{ Perineural invasion } \\
\hline Positive & 9 & $7(77.8)$ & $2(22.2)$ & 0.4 \\
\hline Negative & 51 & $24(47)$ & $27(53)$ & \\
\hline \multicolumn{5}{|l|}{ Lymph node status } \\
\hline Involved & 17 & $8(47)$ & $9(53)$ & 0.1 \\
\hline Not involved & 43 & $23(53.5)$ & $20(46.5)$ & \\
\hline
\end{tabular}

*Statistically significant ( $\mathrm{P}<0.05), 1=\mathrm{NMI}$, Non-muscle invasive, $2=\mathrm{MI}$, Muscle-invasive.

those patients may get benefit from PD-L1 inhibition. Pichler et al. (2017) and Davick et al. (2018) stated that high PD-L1 expression on the tumor cells was more frequently seen in histologic subtypes of urothelial cancerespecially the squamous and sarcomatoid subtypes- compared to pure urothelial cancers ( $46.2 \%$ vs. $20.8 \%$ ). Our results were higher than those of Patel and Kurzrock (2015) who found that PD-L1 expression, was detected in $21 \%$ of their cases (22\% of urothelial carcinomas and $37 \%$ of squamous carcinomas).

Few studies compared PD-L1 expression among urothelial, SCC and adenocarcinoma cases. Necchi et al. (2020) found significant differences in PD-L1 expression among these major subtypes. SCC had the highest frequency of them all, followed by urothelial carcinoma and then adenocarcinoma. The difference in our adenocarcinoma cases results may be related to our small sample size, so we recommend further studies to investigate PD-L1 expression in bladder adenocarcinomas and determine their chance to get benefit from anti PD-L1 therapy.

Immune checkpoint markers are affected by the molecular subtypes and histologic variants of the tumors. Guo and Czerniak (2019) explained the low expression of PD-L1 among conventional urothelial carcinoma and the high PD-L1 expression among squamous and sarcomatoid variants by their molecular subtypes. The expression of PD-L1 is moderately elevated in luminal conventional urothelial carcinoma subtype. Meanwhile, the basal/squamous subtype is associated with a strong expression of PD-L1 and more likely to respond to immune checkpoint therapy. 
Table 3. Relation of p53 expression with different clinicopathological parameters

\begin{tabular}{|c|c|c|c|c|}
\hline Clinicopathological parameters & Cases (No.) & $\begin{array}{l}\text { High p53 } \\
\text { expression } \\
N=30\end{array}$ & $\begin{array}{l}\text { Low p53 } \\
\text { expression } \\
N=30\end{array}$ & P-value \\
\hline \multicolumn{5}{|l|}{ Sex } \\
\hline Male & 47 & $23(48.9)$ & $24(51.1)$ & \multirow{2}{*}{0.754} \\
\hline Female & 13 & $7(53.8)$ & $6(46.2)$ & \\
\hline \multicolumn{5}{|l|}{ Histopathological types } \\
\hline Urothelial carcinoma (Total) & 32 & $17(53.1)$ & $15(46.9)$ & \multirow{7}{*}{0.153} \\
\hline $\begin{array}{l}\text { Low grade non-infiltrating papillary urothelial } \\
\text { carcinoma }\end{array}$ & 8 & $2(25)$ & $6(75)$ & \\
\hline High grade infiltrating urothelial carcinoma & 12 & $6(50)$ & $6(50)$ & \\
\hline $\begin{array}{l}\text { Urothelial carcinoma with squamous } \\
\text { differentiation }\end{array}$ & 10 & $7(70)$ & $3(30)$ & \\
\hline Sarcomatoid urothelial carcinoma & 2 & $2(100)$ & $0(0)$ & \\
\hline Sqaumous cell carcinoma & 25 & $10(40)$ & $15(60)$ & \\
\hline Adenocarcinoma & 3 & $3(100)$ & $0(0)$ & \\
\hline \multicolumn{5}{|l|}{ Grade } \\
\hline $\begin{array}{l}\text { Low } \\
\text { High }\end{array}$ & 39 & $25(64.1)$ & 14 (35.9) & $0.003^{*}$ \\
\hline \multicolumn{5}{|l|}{ Stage } \\
\hline $\begin{array}{l}\mathrm{NMI}^{1}(\mathrm{pTa} \& \mathrm{pT} 1) \\
\mathrm{MI}^{2}(\mathrm{pT} 2, \mathrm{pT} 3 \& \mathrm{pT} 4)\end{array}$ & $\begin{array}{l}20 \\
40\end{array}$ & $25(62.5)$ & $15(37.5)$ & $0.032 *$ \\
\hline \multicolumn{5}{|l|}{ Associated carcinoma in situ } \\
\hline Absent & 45 & $23(51.1)$ & 22 (48.9) & \multirow[t]{2}{*}{0.766} \\
\hline Present & 15 & $7(46.7)$ & $8(53.3)$ & \\
\hline \multicolumn{5}{|l|}{ Vascular invasion } \\
\hline $\begin{array}{l}\text { Positive } \\
\text { Negative }\end{array}$ & 51 & $21(41.2)$ & $30(58.8)$ & $0.0078^{*}$ \\
\hline \multicolumn{5}{|l|}{ Perineural invasion } \\
\hline Positive & 9 & $6(66.7)$ & $3(33.3)$ & \multirow[t]{2}{*}{0.45} \\
\hline Negative & 51 & $24(47)$ & $27(53)$ & \\
\hline \multicolumn{5}{|l|}{ Lymph node status } \\
\hline Involved & 17 & $12(70.6)$ & $5(29.4)$ & \multirow{2}{*}{$0.012^{*}$} \\
\hline Not involved & 43 & $18(41.9)$ & $25(58.1)$ & \\
\hline
\end{tabular}

*Statistically significant ( $\mathrm{P}<0.05), 1=\mathrm{NMI}$, Non-muscle invasive, $2=\mathrm{MI}$, Muscle-invasive.

Table 4. Relation between PD-L1 and P53 expressions

\begin{tabular}{ccc}
\hline & \multicolumn{2}{c}{ P53 (n=60) } \\
PD-L1 & High expression & low expression \\
$(n=60)$ & $(n=30)$ & $(n=30)$ \\
& $N(\%)$ & $\mathbf{N}(\%)$ \\
\hline +ve (n=31) & $20(33.3 \%)$ & $11(18.3 \%)$ \\
-ve (n=29) & $10(16.7 \%)$ & $19(31.7 \%)$ \\
\hline P & $\mathbf{0 . 0 1 2 *}$ \\
\hline
\end{tabular}

*Statistically significant $(\mathrm{P}<0.05)$.

Li et al. (2020) also found that non-invasive papillary urothelial carcinoma was significantly lower in PD-L1 expression than invasive UC, mainly in the squamous and sarcomatoid histologies, compared to the other variants. Mak et al. (2016) and Lerner et al. (2017) stated that the basal/squamous subtype is much sensitive to anti-PD-L1/PD-1 compared with papillary luminal tumors.
So, we support that certain histological variants (squamous and sarcomatoid) and molecular subtypes (basal/squamous) tend to show positive PD-L1, and therefore may be appropriate for anti PD-L1 immune checkpoint therapy. Further researches involving the different variants and molecular subtypes may provide a benefit for urinary bladder carcinoma patients'.

In our study, positive PD-L1 expression was significantly associated with high grade and muscle-invasive cases.Our results match those of Huang et al. (2015) and Kawahara et al. (2018) who stated that PD-L1 expression on bladder carcinoma tumor cells was related to high tumor grade, muscle-invasive disease, increased resistance to Bacillus CalmetteGuerin (BCG) therapy and worse overall survival. 
Ding et al. (2019) found no significant relation between PD-L1 expression on bladder carcinoma tumor cells and higher tumor grade, lymph node and distant metastases, but it was associated with muscle-invasion, suggesting that positive PD-L1 expression could be a potential prognostic marker for patients with bladder cancer. Also, Davick et al. (2018) and Owyong et al. (2019) reported that high PD-L1, was significantly associated with higher tumor stage, distant metastasis and poor overall survival, but not with sex, tumor grade, lymph node status, and multifocality.

P53 -the guardian of the genome- is one of the most widely studied molecular markers in bladder carcinoma. Regarding p53 immunohistochemical results, high p53 expression was found in $50 \%$ of our studied cases. There was a statistically significant relation between p53 expression and high tumor grade (64.1\% of high-grade cases), advanced tumor stage $(62.5 \%$ of muscleinvasive cases), the presence of vascular invasion and lymph node metastases. No statistically significant difference -in p53 expression- was found between urothelial, SCC and adenocarcinoma cases.

Our results were in agreement with Thakur et al. (2017) who stated that high p53 expression was significantly associated with high tumor grade, muscle-invasion, decreased disease-free (DFS), cancer-specific (CSS), and overall survival (OS), suggesting that p53 is an independent poor prognostic factor in urinary bladder carcinoma patients'. P53 regulates immune responses by targeting immune checkpoints, including PD-L1. PD-L1 expression is lost or shows decreased expression in cells that have wild-type p53, suggesting that induction of wild-type p53 down-regulates PD-L1 expression (Cortez et al., 2016).

Few studies explored the relation between PDL1 and p53 expression in urinary bladder carcinoma. Previous studies focused mainly on their relationship in non-small cell lung cancer (NSCLC). In our study, there was a statistically significant relation between PD-L1 and p53 expression.
Dong et al. (2017), Kadara et al. (2017), Wieser et al. (2018) and Kang et al. (2020) stated that p53 mutation is associated with elevated PD-L1 expression in lung and ovarian cancinoma. Jiang et al. (2015) and Yu et al. (2018) studied PD-L1 and p53 expression in pulmonary lymphoepithelioma-like carcinoma patients, and detected high PD-L1 expression levels in p53-mutated tumors, compared to the p53negative group. They also stated that PD-L1 and P53 may predict benefit from adjuvant therapy in these cases.

Cortez et al. (2016) supported the inverse relationship of $\mathrm{p} 53$ and PD-L1 expression in vivo, using p53-wild type and p53-mutated NSCLC samples. NSCLC tumors with mutated p53, showed a statistically significant higher PD-L1 expression than wild-type p53 tumors. Cha et al. (2016) also, studied PD-L1 and p53 expression in lung adenocarcinoma, and found that PD-L1 positive tumors were significantly associated with mutant p53 expression. Tojyo et al. (2019) found a significant positive association between PD-L1 and p53 expressions in oral squamous cell carcinoma.

On the contrary, Rashed et al. (2017) found no significant association between p53 and PD-L1 expression in their study on NSCLCs Egyptian patients. Despite these previous studies, the relation between PD-L1 and p53 is still poorly understood (Shen et al., 2019).

\section{CONCLUSIONS}

This study coclude that PD-L1 and p53 are considered predicting antibodies for high grade muscle-invasive urinary bladder carcinoma, and that their immunohistochemical expression could be affected by the histological types and may aid in identifying suitable patients for target therapy. Nevertheless, we recommend additional studies to evaluate the expression of PD-L1 in different histopathological bladder carcinoma variants and molecular subtypes, and the mechanisms that link p53 mutation and PDL1 expression in urinary bladder carcinoma for establishing new therapeutic modalities.

\section{CONFLICT OF INTEREST}

Authors declare that they have no conflicts of interest. 


\section{FUDING}

There is no financial support for this study.

\section{REFERENCES}

Amin MB, Edge SB, Greene FL, Byrd DR, Brookland RK, Washington MK, Gershenwald JE, Compton CC, Hess KR, Sullivan DC, Jessup JM, Brierley JD, Gaspar LE, Schilsky RL, Balch CM, Winchester DP, Asare EA, Madera M, Gress DM, Vega LM 2017 eds.: AJCC Cancer Staging Manual. AJCC: Urinary bladder. 8th edition. New York, NY: Springer,14:pp 757-765.

Bellmunt J, Mullane SA, Werner L, Fay AP, Callea M, Leow JJ, Taplin ME, Choueiri TK, Hodi FS, Freeman GJ, Signoretti S (2015). Association of PD-L1 expression on tumor-infiltrating mononuclear cells and overall survival in patients with urothelial carcinoma. Ann Oncol, 26(4):812-817.

Bellmunt J, Powles T, Vogelzang NJ (2017). A review on the evolution of PD-1/PD-L1 immunotherapy for bladder cancer: The future is now. Cancer Treat Rev, 54:58-67.

Brahmer JR, Tykodi SS, Chow LQM, Hwu WJ, Topalian SL, Hwu P, Drake CG, Camacho LH, Kauh J, Odunsi K, Pitot HC, Hamid O, Bhatia S, Martins R, Eaton K, Chen S, Salay TM, Alaparthy S, Grosso JF, Wigginton JM (2012). Safety and activity of anti-PD-L1 antibody in patients with advanced cancer. $N$ Engl J Med, 366(26):2455-2465.

Braun MW, Iwakuma T. Regulation of cytotoxic T-cell responses by p53 in cancer (2016). Transl Cancer Res, 5(6):692-697.

Cha YJ, Kim HR, Lee CY, Cho BC, Shim HS (2016). Clinicopathological and prognostic significance of programmed cell death ligand1 expression in lung adenocarcinoma and its relationship with p53 status. Lung Cancer, 97:73-80.

Charlton ME, Adamo MP, Sun L, Deorah S (2014). Bladder cancer collaborative stage variables and their data quality, usage, and clinical implications: a review of SEER data, 20042010. Cancer, 120(23):3815-3825.

Cortez MA, Ivan C, Valdecanas D, Wang X, Peltier HJ, Ye Y, Araujo L, Carbone DP, Shilo K, Giri DK, Kelnar K, Martin D, Komaki R, Gomez DR, Krishnan S, Calin GA, Bader AG, Welsh JW (2016). PDL1 Regulation by p53 via miR-34. J Natl Cancer Inst,108(1):djv303.

Davick JJ, Frierson HF, Smolkin M, Gru AA (2018). PDL1 expression in tumor cells and the immunologic milieu of bladder carcinomas: a pathologic review of 165 cases. Hum Pathol, 81:184-191.
Ding X, Chen Q, Yang Z, Li J, Zhan H, Lu N, Chen M, Yang Y, Wang J, Yang D (2019). Clinicopathological and prognostic value of PD-L1 in urothelial carcinoma: a metaanalysis. Cancer Manag Res, 11:4171-4184.

Dong ZY, Zhong WZ, Liu SY, Xie Z, Wu SP, Wu YL (2017). Potential Predictive Value of TP53 and KRAS Mutation Status for Response to PD-1 Blockade Immunotherapy in Lung Adenocarcinoma. J Thorac Oncol,12(1):S432S433.

Favaretto RL, Zequi SC, Oliveira RAR, Santana T, Costa WH, Cunha IW, Guimarães GC (2018). Tissue-based molecular markers in upper tract urothelial carcinoma and their prognostic implications. Int Braz J Urol, 44(1):22-37.

Gatalica Z, Snyder C, Maney T Ghazalpour A, Holterman DA, Xiao N, Overberg P, Rose I, Basu GD, Vranic S, Lynch HT, Von Hoff DD, Hamid O (2014). Programmed Cell Death 1 (PD-1) and Its Ligand (PD-L1) in Common Cancers and Their Correlation with Molecular Cancer Type. Cancer Epidemiol Biomarkers Prev, 23(12):2965-2970.

Guo CC, Czerniak B (2019). Bladder Cancer in the Genomic Era. Arch Pathol Lab Med,143(6):695-704.

Heinemann A, Zhao F, Pechlivanis S, Eberle J, Steinle A, Diederichs S, Schadendorf D, Paschen A (2012). Tumor suppressive microRNAs miR-34a/c control cancer cell expression of ULBP2, a stress-induced ligand of the natural killer cell receptor NKG2D. Cancer Res,72:460-71.

Huang Y, Zhang SD, Mccrudden C, Chan KW, Lin Yao, Kwok HF (2015). The prognostic significance of PD-L1 in bladder cancer. Oncol Rep, 33(6):3075-3084.

Humphrey PA, Moch $H$, Cubilla AL, Ulbright TM, Reuter VE (2016). The 2016 WHO Classification of Tumours of the Urinary System and Male Genital Organs-Part B: Prostate and Bladder Tumours. Eur Urol, 70(1):106-119.

Jankevicius F, Goebell P, Kushima M, Schulz WA, Ackermann R, Schmitz-Dräger BJ (2002). p21 and p53 Immunostaining and Survival following Systemic Chemotherapy for Urothelial Cancer. Urol Int, 69(3):174-180.

Jiang L, Wang L, Li PF, Zhang X, Chen J, Qiu H, Wu X, Zhang B (2015). Positive expression of programmed death ligand-1 correlates with superior outcomes and might be a therapeutic target in primary pulmonary lymphoepithelioma-like carcinoma. Onco Targets Ther, 8:1451-7. 
Kadara H, Choi M, Zhang J, Parra ER, RodriguezCanales J, Gaffney SG, Zhao Z, Behrens C, Fujimoto J, Chow C, Yoo Y, Kalhor N, Moran C, Rimm D, Swisher S, Gibbons DL, Heymach J, Kaftan E, Townsend JP, Herbst RS (2017). Whole-exome sequencing and immune profiling of early-stage lung adenocarcinoma with fully annotated clinical follow-up. Ann Oncol Off J Eur Soc Med Oncol, 28(1):75-82.

Kang DY, Sp N, Jo ES, Rugamba A, Hong DY, Lee HG, Yoo JS, Liu Q, Jang KJ, Yang YM (2020). The Inhibitory Mechanisms of Tumor PD-L1 Expression by Natural Bioactive Gallic Acid in Non-Small-Cell Lung Cancer (NSCLC) Cells. Cancers, 12(3):727.

Kawahara T, Ishiguro Y, Ohtake S, Kato I, Ito $\mathrm{Y}$, Ito H, Makiyama K, Kondo K, Miyoshi Y, Yumura $Y$, Hayashi N, Hasumi H, Osaka K, Muraoka K, Izumi K, Teranishi Jl, Uemura H, Yao M, Nakaigawa N (2018). PD-1 and PD-L1 are more highly expressed in high-grade bladder cancer than in low-grade cases: PD-L1 might function as a mediator of stage progression in bladder cancer. BMC Urol,18(1):97.

Lerner SP, Robertson G, Kim J, Cherniack A, Guo G, Akbani R, Kanchi RS, Hoadley KA, Hinoue T, Laird PW, Al-Ahmadie H, Bellmunt J, Castro M, Gordenin D, Mills GB, Sanchez-Vega F, Shukla SA, Gibb EA, Weinstein JN, Kwiatkowski DJ (2017). Comprehensive molecular characterization and analysis of muscle-invasive urothelial carcinomas. J Clin Oncol, 35(15_suppl):4500.

Li H, Zhang Q, Shuman L, Kaag M, Raman JD, Merrill S, DeGraff DJ, Warrick JI, Chen G (2020). Evaluation of PD-L1 and other immune markers in bladder urothelial carcinoma stratified by histologic variants and molecular subtypes. Sci Rep,10(1):1439.

Mak MP, Tong P, Diao L, Cardnell RJ, Gibbons DL, William WN, Skoulidis F, Parra ER, RodriguezCanales J, Wistuba II, Heymach JV, Weinstein JN, Coombes KR, Wang J, Byers LA (2016). A Patient-Derived, Pan-Cancer EMT Signature Identifies Global Molecular Alterations and Immune Target Enrichment Following Epithelial-to-Mesenchymal Transition. Clin Cancer Res, 22(3):609-620.

Morsch R, Rose M, Maurer A, , Cassataro MA, Braunschweig T, Knüchel R, Vögeli TA, Ecke T, Eckstein M, Weyerer V, Esposito I, Ackermann M, Niegisch G, Gaisa NT (2020). Therapeutic implications of PD-L1 expression in bladder cancer with squamous differentiation. BMC Cancer, 20(1):230.

Muñoz-Fontela C, Mandinova A, Aaronson SA, Lee SW (2016). Emerging roles of p53 and other tumour-suppressor genes in immune regulation. Nat Rev Immunol, 16(12):741-750.

Necchi A, Madison R, Raggi D, Jacob JM, Bratslavsky G, Shapiro O, Elvin JA, Vergilio JA, Killian JK, Ngo N, Ramkissoon S, Severson E, Hemmerich AC, Huang R, Ali SM, Chung JH, Reddy P, Miller VA, Schrock AB, Ross JS (2020). Comprehensive Assessment of Immunooncology Biomarkers in Adenocarcinoma, Urothelial Carcinoma, and Squamous-cell Carcinoma of the Bladder. Eur Urol, 77(4):548-556.

Owyong M, Lotan Y, Kapur P, Panwar V, McKenzie T, Lee TK, Zi X, Martin JW, Mosbah A, Abol-Enein $H$, Ghoneim M, Youssef RF (2019). Expression and prognostic utility of PD-L1 in patients with squamous cell carcinoma of the bladder. Urol Oncol Semin Orig Investig, 37(7):478484.

Pardoll DM (2012). The blockade of immune checkpoints in cancer immunotherapy. Nat Rev Cancer, 12(4):252-264.

Patel SP, Kurzrock R (2015). PD-L1 Expression as a Predictive Biomarker in Cancer Immunotherapy. Mol Cancer Ther, 14(4):847856.

Pichler R, Heidegger I, Fritz J, Danzl M, Sprung S, Zelger B, Brunner A, Pircher A (2017). PD-L1 expression in bladder cancer and metastasis and its influence on oncologic outcome after cystectomy. Oncotarget, 8(40):66849-66864.

Rashed HE, Abdelrahman AE, Abdelgawad M, Balata S, Shabrawy ME (2017). Prognostic significance of programmed cell death ligand 1 (PD-L1), CD8+ tumor-infiltrating lymphocytes and p53 in non-small cell lung cancer: An immunohistochemical study. Turk Patoloji Derg,1:211-22.

Rodríguez-Alonso A, Pita-Fernández S, GonzálezCarreró J, Nogueira-March JL (2002). p53 and ki67 Expression as Prognostic Factors for Cancer-Related Survival in Stage T1 Transitional Cell Bladder Carcinoma. Eur Urol, 41(2):182-189.

Shariat SF, Bolenz C, Karakiewicz PI, Fradet Y, Ashfaq R, Bastian PJ, Nielsen ME, Capitanio U, Jeldres C, Rigaud J, Müller SC, Lerner SP, Montorsi F, Sagalowsky Al, Cote RJ, Lotan Y (2010). p53 expression in patients with advanced urothelial cancer of the urinary bladder. BJU Int,105(4):489-495.

Sharpe AH, Wherry EJ, Ahmed R, Freeman GJ (2007). The function of programmed cell death 1 and its ligands in regulating autoimmunity and infection. Nat Immunol, 8(3):239-245.

Shen X, Zhang L, Li J, Li Y, Wang Y, Xu ZX (2019). Recent Findings in the Regulation of 
Programmed Death Ligand 1 Expression. Front Immunol,10:1337.

Siegel RL, Miller KD, Jemal A (2019). Cancer statistics, 2019. CA Cancer J Clin, 69(1):7-34.

Thakur B, Kishore S, Dutta K, Kaushik S, Bhardwaj A (2017). Role of p53 and Ki-67 immunomarkers in carcinoma of urinary bladder. Indian $J$ Pathol Microbiol, 60(4):505.

Tojyo I, Shintani Y, Nakanishi T, Okamoto K, Hiraishi Y, Fujita S, Enaka M, Sato F, Muragaki Y (2019). PD-L1 expression correlated with p53 expression in oral squamous cell carcinoma. Maxillofac Plast Reconstr Surg,41(1):56

Topalian SL, Brahmer JR, Hodi FS, McDermott DF, Smith DC, Gettinger S, Taube JM, Gupta A, Wigginton JM, Sznol M (2012). AntiProgrammed Death-1 (PD-1) in Patients (PTS) with Advanced Solid Tumors: Clinical Activity, Safety, and Molecular Markers. Ann Oncol, 23:ix157.

Wieser V, Gaugg I, Fleischer M, Shivalingaiah G, Wenzel S, Sprung S, Lax SF, Zeimet AG, Fiegl $H$, Marth C (2018). BRCA $1 / 2$ and TP53 mutation status associates with PD-1 and PDL1 expression in ovarian cancer. Oncotarget, 9(25):17501-17511.

Yu XY, Zhang XW, Wang F, Lin YB, Wang WD, Chen YQ, Zhang LJ, Cai L (2018). Correlation and prognostic significance of PD-L1 and P53 expression in resected primary pulmonary lymphoepithelioma-like carcinoma. J Thorac Dis,10(3):1891-1902. 


\section{Egyptian Association for Cancer Research (EACR)}

http://eacr.tanta.edu.eg/

EACR is an NGO society that was declared by the Ministry of Social Solidarity (Egypt) No. 1938 in 19/11/2014 based on the initiative of Prof. Mohamed Labib Salem, the current Chairman of EACR. EACR aims primarily to assist researchers, in particular young researchers in the field of cancer research through workshops, seminars and conferences. Its first international annual conference entitled "Anti-Cancer Drug Discovery" was successfully organized in April 2019 (http://acdd.tanta.edu.eg). Additionally, EACR aims to raise the awareness of the society about the importance of scientific research in the field of cancer research in prediction, early diagnosis and treatment of cancer. EACR is also keen to outreach the scientific community with periodicals and news on cancer research including peer-reviewed scientific journals for the publication of cutting-edge research. The official scientific journal of EACR is "International Journal of Cancer and biomedical Research (IJCBR: https://jcbr.journals.ekb.eg) was successfully issued in 2017 and has been sponsored by the Egyptian Knowledge Bank (EKB: www.ekb.eg).

\section{EACR Chairman,}

Prof. Mohamed Labib Salem, PhD

Professor of Immunology

Faculty of Science, Tanta Universiy, Egypt 


\section{GUIDE FOR AUTHORS}

Publisher :The International Journal of Cancer and Biomedical Research (IJCBR) is an International and interdisciplinary journal of preclinical and clinical studies in the area of cancer and biomedical research. It is a peer-reviewed journal in English, published quarterly (in March, June, September, and December) by the Egyptian Association for Cancer Research (EACR) in both print and online formats (4 issues making a volume). Special issues or supplements may also be produced from time to time upon agreement with the Editorial Board.

Scope :The main aim of IJCBR is to attract the best research in animal and human biology in health and diseases from across the spectrum of the biomedical sciences at the molecular, cellular, organ, and whole animal levels especially those that are related to cancer research, including causes, prediction, diagnosis, prognosis, and therapy.

Publication Fees :The journal does charge for submission, processing, or publication of manuscripts (2000 LE for Egyptians or $250 \$$ for non-Egyptians; EACR members receive 15\% discount on publication). Of them Peer-review fees (300 LE) should be paid on submission (non-refundable). For the fast-track production of the accepted manuscript, another 500 LE is paid.

General specifications for different types of article

- Submitted manuscripts should not have been published previously, except in a limited form (e.g. short communication to a symposium or as part of MSc or PhD theses) and should not be under consideration for publication by other journals.

- All co-authors should agree with the content of the manuscript. Authors must have obtained permission to use any copyrighted material in the manuscript before submission.

IJCBR publishes different types of articles

- Original Article (6000 words with $\mathbf{4}$ tables and $\mathbf{4}$ figures, maximum $\mathbf{8}$ display items): Articles with novel findings are the target of IJCBR. Articles presenting a detailed description of a new technique, comparison of existing methods, meta-analyses with comprehensive and in-depth discussion are considered. Papers in a numbered series are not accepted unless all are submitted at the same time.

- Short communications or case study (3000 words with $\mathbf{4}$ display items): Short communications present exceptionally exciting, novel or timely contents are considered. They will be peer-reviewed in the same way as research papers. The references are restricted to 15 .

- Reviews or systematic review (9000 words with $\mathbf{1 0}$ display items): They are invited by the Editorial Board or unsolicited. Review articles have to be contemporary and comprehensive and add information to the knowledge. Sharp critical analyses of novel data or concepts are encouraged. When relevant, a statistical analysis of data and a meta-analysis approach are recommended.

- Opinion papers, letter to the editor or comment to the editor (1500 words with $\mathbf{2}$ display items): They are submitted by invitation of the Editorial Board. They are short papers, which aim to inform scientists, industry, and the public and policymakers about cutting-edge issues in research or the impact of research. They reflect the opinion of their authors who bear full responsibility of the published paper. The references are restricted to 10 .

- Conference/Symposium papers: The journal will consider for publication the results of original work and critical reviews that are presented at conferences/symposia. Symposium organizers who wish to publish bundles of papers from a symposium/conference in IJCBR should first contact the Editor-in-Chief of the IJCBR (EACR@unv.tanta.edu.eg) for agreement. Supplementary material can be proposed and will be made available online. The responsibility for the preparation of a paper in a form suitable for publication lies with the author.

- Thesis: IJCBR can publish the summary and abstract of Master and PhD theses in a special issue.

English: Good quality of written English is required. Spelling may be in British or American English but must be consistent throughout the paper. Care should be exercised in the use of biological terminology that is ill-defined or of local familiarity only. We recommend that authors have their manuscripts checked by an English language native speaker before submission.

Manuscript layout: Manuscripts should be prepared using a standard word processing program and presented in a clear readable format with easily identified sections and headings. The manuscript layout is based on the following directions.

- The main text contains Title, Abstract, Keywords, Introduction, Material and Methods, Results, Discussion, References, Tables, figures.

- The title needs to be concise and informative. Use bold, with an initial capital for the first word only and for words that ordinarily take capitals.

- Short (running) title (max 80 characters including spacing).

- The article text should be typed with double line spacing with wide margins $(2.5 \mathrm{~cm})$.

- The lines must be continuously numbered; the pages must also be numbered.

- Font Calibri 12 should be used for the text, and 12 for the tables, figure legends and references.

- The sections should typically be assembled in the following order:

- Title page contains title, authors' names, full affiliations, acknowledgements and the corresponding author's contacts and Short title.

Abstract (max 250 words, single paragraph): The abstract should be complete and understandable without citation, references, table, or figure. Use structured abstract: Background, Aim, Materials \& Methods, Results and Conclusion. The context and the rationale of the study are presented succinctly to support the objectives. The experimental methods and main results are summarized but should not be overburdened by numerical values or probability values. The abstract ends with a short and clear conclusion. 
Keywords: Up to five short and specific keywords should complement the title with respect to indicating the subject of the paper in alphabetic order.

Introduction: The introduction briefly outlines the context of the work, presents the current issues that the authors are addressing and the rationale to support the objectives, and clearly defines the objectives.

Material and methods: Material and methods should be described in sufficient details so that others can repeat the experiment. Reference to previously published work may be used to give methodological details, provided that said publications are readily accessible and in English. The code of ethics should be followed for all experiments use animals or human samples.

Statistical analysis of results: The statistical design and the models of statistical analysis must be described, as well as each of the statistical methods used. Sufficient statistical details must be given to allow replication of the statistical analysis. The experimental unit should be defined (e.g., individual or group of animals).

Results: Data are presented as tables and figures. Brief description of the results for each table and figure should be presented. Unpublished data can be mentioned when necessary.

Discussion: Should be separate from the Results section and should focus only on intra- and inter-data discussion (the data in the results section) as well as with the relative data in the literature. Don't repeat information already presented in the Introduction section. Start the first paragraph in the Discussion with a paragraph stating the rationale behind the study, the objectives, and the main findings. End Discussion with a short conclusion.

Acknowledgements: In this section, the authors may acknowledge (briefly) their support staff.

Conflict of interest: All papers with a potential conflict of interest must include a description/explanation in a separate heading.

Funding details: The authors should state the source of findings of the study (with research funder and/or grant number). If no fund, the authors should state that the study is self-funded.

\section{References}

Citation of references: In the text, references should be cited by the author(s) surname(s) and the year of publication (e.g. Salem, 2020). References with two authors should be cited with both surnames (e.g. Salem and Meshrif, 2021). References with three or more authors should be cited with the first author followed by et al. (in italics; e.g. Salem et al., 2021). Names of organizations used as authors (e.g. Food and Drug Administration) should be written out in full in the list of references and on the first mention in the text. Subsequent mentions may be abbreviated (e.g. FDA).

- List of references. Literature cited should be listed in alphabetical order by authors' names. It is the author's responsibility to ensure that all references are correct. All authors should be written and so the full journal name.

- $\quad$ References from journal articles are formatted in APA as this example: Al-Amoudi WM (2018). Toxic effects of Lambdacyhalothrin on the rat thyroid. Involvement of oxidative stress and ameliorative effect of ginger extract. Toxicology Reports, 5: 728-736.

- $\quad$ References from books or official reports are formatted as this example. Kebreab E, Dijkstra ANM, Bannink A, Gerrits WJJ, \& France J (2006). Nutrient digestion and utilization in farm animals. CABI Publishing. Wallingford, UK.

- References from chapters or parts of books are formatted as this example. Nozière $P, \&$ Hoch $T$ (2006). Modelling fluxes of volatile fatty acids from rumen to portal blood. In: Nutrient digestion and utilization in farm animals (Kebreab E, Dijkstra ANM, Bannink A, Gerrits WJJ \& France J, eds.), pp. 40-47. CABI Publishing. Wallingford, UK.

Tables: The data should be presented in tables or in graphs, not both.

- Each table should be placed on a separate page at the end of the main text.

- Tables are numbered consecutively using Arabic numbering. They are referred to as Table 1 , Table 2, etc., with capital ' $T$ ', no italics

- $\quad$ Each table has its explanatory caption. The caption is sufficient to permit the table to be understood without reference to the text.

- Abbreviations used in tables/figures have to be defined either as footnotes or in the caption.

\section{Figures}

- $\quad$ Package the figures in a single PowerPoint file. Each figure in a separate slide.

- Figure size should be readable in a width of approximately 8-175 $\mathrm{mm}$ (i.e. the maximum size of printing over two columns).

- Ensure that the font size is large enough to be readable at the final print size, use Calibri font to ensure that they are consistent throughout the figures.

- $\quad$ The figures should preferably be provided as TIFF or EPS files.

- The resolutions of figures must be at least $300 \mathrm{dpi}$.

- Preparation of images for a manuscript: For guidance, we refer to the Journal of Cell Biology's instructions to authors (http://jcb.rupress.org/site/misc/ifora.xhtml\#image_aquisition).

- If a cropped image is included in the main text of a paper (e.g. a few lanes of a gel), display the full original image, including the appropriate controls, the molecular size ladder and/or the scale as relevant, as a single figure in a Supplementary Material file to facilitate peer-review and for subsequent online publication.

- Supplementary material is submitted along with the main manuscript in a separate file and identified at uploading as "Supplementary File - for Online Publication Only" The title of the article is included at the top of the supplementary material.

Corresponding author's guidelines: Upon acceptance the corresponding author is required to send his/her recent formal photo to be attached to the front page of the article. 


\title{
International Journal of Cancer \& Biomedical Research
}

(IJCBR) Online ISSN 2682-2628

\author{
Editor-in-Chief \\ Mohamed Labib Salem, PhD \\ Tanta University, Egypt
}

\begin{tabular}{l} 
EACR Board \\
\hline Nehal Elmashad, MD \\
Tanta University, Egypt \\
Nabil Mohy Eldin, PhD \\
Kafrelsheikh University, Egypt \\
Doaa Al-Ghareeb, PhD \\
Alexandria University, Egypt \\
Abdel-Aziz Zidan, PhD \\
Damanhour University, Egypt
\end{tabular}

\begin{tabular}{l} 
Managing Editor \\
\hline Wesam Meshrif, PhD \\
Tanta University, Egypt \\
Sohaila Galal, PhD \\
Tanta University, Egypt \\
Production and Contact \\
\hline Hamdi Kandil \\
Tanta University, Egypt \\
Email: ljcbr100@gmail.com
\end{tabular}

\section{Advisory Board}

Alberto Montero, MD

Taussig Cancer Center, Cleveland,

USA

Yi Zhang, MD

Zhengzhou University, China

Mark Robunstein, Ph D

Medical University of South

Carolina, USA

Mohsen Farid, Ph D

Derby University, USA

Natarajan Muthusamy, Ph D

Ohio State University, USA

Hideki Kasuya, MD

Nagoya University, Japan

Sherif El-Khamisy, Ph D

Sheffield University, UK

Mohamed Ghanem, Ph D

Kafr Elshikh University, Egypt

Sayed Bakry, Ph D

Alazhar University, Egypt

Sameh Ali, Ph D

Nationa Liver Institute, Egypt

Gamal Badr, Ph D

Assuit University, Egypt

Nadia Hamdy, Pharm D

Ain Shams University, Egypt

\section{Editorial Board}

\section{Clinical studies}

Hesham Tawfik, MD

Tanta University, Egypt

Mohamed Attia, MD

Tanta University, Egypt

Mohamed Elshanshory, MD

Tanta University, Egypt

Essam Elshiekh, MD

Tanta Cancer Center, Egypt

Rasha Eraky, MD

Tanta University, Egypt

Shaima Abou-Kjatwa, MD

Tanta University, Egypt

Marcela Diaz, MD

Cleveland Clinic Foundation, USA

Mohamed Abou-El-Enein, MD

Charité Universitätsmedizin Berlin,

Germany
Alaa Eldin Almostafa, MD

McGill University, Canada

Olfat Gadallah, MD

Tanta University, Egypt

Nagla Sarhan, MD

Tanta University, Egypt

Naglaa Fathy, Pharm D

Zagazik University, Egypt

Mohamed Salama, MD

Mansoura University, Egypt

Mona Marie, MD

Alexandria University, Egypt

Preclinical studies

Mostafa El-Sheekh

Tanta University, Egypt

El-Refai Kenawy, Ph D

Tanta University, Egypt

Mohamed Noureldin, Ph D

Banaha University, Egypt

Yousry Albolkiny, Ph D

Tanta University, Egypt

Elsayed Salim, Ph D

Tanta University, Egypt

Shengdian Wang, Ph D

Chinese Academy of Sciences,

China

Sabry El Naggar, Ph D

Tnata Univesity, Egypr

Faris Alenzi, Ph D

Prince Sattam bin Abdulaziz

University, KSA

Ibrahim El-Sayed, Ph D

Menoufia University, Egypt

Tarek Aboul-Fadl, Ph D

Assiut University, Egypt

Rabab Khairat, Ph D

National Research Center,

Giza, Egypt

Wael Lotfy, Ph D

Alexandria University, Egypt

Ashraf Tabll, Ph D

National Research Center, Egypt

Nahla Shoukry, Ph D

Suez University, Egypt
Medhat Eldenary, Ph D

Tanta University, Egypt

Azza Hasan, Ph D

Menufia University, Egypt

Nanees Gamal Eldin, Ph D

Tanta University, Egypt

Mohamed Mansour, UK

Sabbah Hammoury, Ph D

Alexandria Ayadi Almostaqba

Oncology Hospital, Egypt

Nehal Aboulfotoh, Ph D

Zewail City for Science and

Technology, Cairo, Egypt

Amir Elkhami, Ph D

Galaxo, San Francisco, USA

Ahmed Alzohairy, Ph D

Zagazi University, Egypt

Wgady Khalil, Ph D

National Research Center, Egypt

Amr Amin, Ph D

United Arab Emirates

University, UAE

AbdelRahman Zekri, Ph D

National Cancer Institute, Egypt

Hussein Khamis, Ph D

Alexandria University, Egypt

Magdy Mahfouz, Ph D

Kafr Elsheikh University, Egypt

Ehab Elbedewey, Ph D

Tanta University, Egypt

Abeer Badr, Ph D

Cairo University, Egypt

Mamdooh Ghoneum, Ph D

Charles Drew University of

Medicine \& Science, USA

Haiam Abou Elela, Ph D

National Institute of Oceanography and Fisherie, Egypt

Maha EL-Demellawi, Ph D City for Scientific Research \&

Technology Applications, Egypt

Desouky Abd-El-Haleem, Ph D

City for Scientific Research \&

Technology Applications, Egypt 